DOI: $10.18203 / 2320-1770 . i j r \operatorname{cog} 20150067$

Research Article

\title{
Testicular cytology in azoospermia
}

\author{
${\text { Usha } \operatorname{Prasad}^{1} \text {, Uma Prasad }}^{2}$ \\ ${ }^{1}$ Department of Obstetrics \& Gynecology, Andhra Medical College, Visakhapatnam, Andhra Pradesh, India \\ ${ }^{2}$ Department of Pathology, RIMS, Srikakulam, Andhra Pradesh, India
}

Received: 08 March 2015

Revised: 13 March 2015

Accepted: 19 April 2015

\author{
*Correspondence: \\ Dr. Usha Prasad, \\ E-mail: usha1966411@gmail.com, ushaprasad411@gmail.com
}

Copyright: $\odot$ the author(s), publisher and licensee Medip Academy. This is an open-access article distributed under the terms of the Creative Commons Attribution Non-Commercial License, which permits unrestricted non-commercial use, distribution, and reproduction in any medium, provided the original work is properly cited.

\begin{abstract}
Background: Male infertility is a common problem and needs a minimally invasive method to arrive at the appropriate diagnosis. Alternative to open testicular biopsy the fine needle aspiration cytology of the testis is being increasingly used as a minimally invasive method of evaluating testicular function. Aim of the study: To assess the diagnostic accuracy of fine needle aspiration cytology in determining the causes of azoospermia. To establish that FNAC is cost effective, safe, out-patient investigation with no complications.

Methods: Thirty nine patients with azoospermia in the age group of 20-40 years were included in the study. All the cases were subjected for Doppler study to rule out varicocele. Cord block was achieved with $1 \%$ lignocaine and aspiration was done with 23 gauge 1.5 inch needle. Smears were made on albuminised slides and stained with Leishman stain. Forresta et al. scoring system was adopted to analyse the smears. In the same sitting testicular biopsy was taken, fixed in Bouin's fluid, routinely processed and stained with H\&E stain.

Results: The commonest group with infertility were in the age group 21-30 years. The testicular size was normal in $87.17 \%$ of subjects and $12.82 \%$ had small testis. Out of 39 subjects with azoospermia $38.46 \%$ subjects had varicocele. Varicocele was commonly associated with duct obstruction. The commonest causes observed in cases with azoospermia were; hypospermatogenesis with maturation arrest $(4 / 39,10.25 \%)$, duct obstruction $(12 / 39,30.76 \%)$, maturation arrest $(7 / 39,17.94 \%)$, testicular atrophy $(10 / 39,25.64 \%)$ and sertoli cell only syndrome $(2 / 39,5.12 \%)$. In the present study diagnostic accuracy was $89.18 \%$.

Conclusions: Fine needle aspiration cytology is as informative as biopsy and can be done as a routine procedure. It helps us in ruling out obstructive and non-obstructive causes for azoospermia. In cases where FNAC shows normal spermatogenesis with azoospermia, biopsy and Doppler study is indicated to rule out duct obstruction which can be corrected surgically. It is a simple and cost effective.
\end{abstract}

Keywords: Needle aspiration, Azoospermia, Cytology, Histology

\section{INTRODUCTION}

Since times immemorial the wife has always been blamed for infertility, the possibility of treatment of the male for infertility is a recent one. Failure to find sperms in a post coital test, conducted by Max Huhner in 1913, ${ }^{1}$ raised the possibility that husband could be responsible for infertility. The available statistics show that the male factor is responsible for about $40 \%$ to $50 \%$ of all cases of sterility.
Assessment of male infertility involves clinical examination of gonads, secondary sexual characteristics, semen analysis, hormonal investigations and morphological examination of testicular biopsy. Open biopsy has proven to be important procedure to classify the pathogenesis of male infertility and to determine the prognosis. However this method is invasive and traumatic, requires anaesthesia which makes this technique difficult to use as a routine method. 
Fine needle aspiration of testis is seldom performed in routine practice due to various reasons including poor compliance and apprehension on the part of the person performing the procedure. With many pathologists taking interest in FNAC there is standardisation of this procedure leading to a good correlation between cytology and histology of the testis. Azoospermia account for about $10-15 \%$ of male infertility. It denotes different testicular alterations ranging from non-obstructive to obstructive azoospermia which could be corrected surgically. ${ }^{2-4}$ The present study is conducted to examine whether FNAC of testis is as effective as conventional biopsy to determine the causes of azoospermia, so that unnecessary and expensive intervention can be avoided and to decide under what circumstances testicular biopsy is definitely indicated.

\section{METHODS}

Subjects with infertility who visited the Government General Hospital at a tertiary care center were included in the study. This is a prospective study for a period of two years. The age of the patients varied from 2040years.After taking history and evaluating the patient clinically, Semen analysis was done thrice with an interval of three weeks between the samples. Thirty nine subjects with azoospermia were analysed. All the thirty nine patients were subjected to Doppler study to diagnose varicocele. The subjects were subjected to Fine Needle Aspiration Cytology (FNAC) and biopsy in the same sitting under aseptic conditions.

The procedure of aspiration was explained to the subject and after taking consent, the subject was placed in supine position, the testis was cleaned with spirit swab and draped in the usual sterile fashion. $2 \mathrm{ml}$ of $1 \%$ lignocaine was infiltrated into the spermatic cord by fixing the vas deferens just beneath the scrotal skin using three finger technique. Lignocaine was injected along the vas deferens with a 25 gauge 1.5 inch needle. A few minutes were allowed to lapse after the injection for the anesthetic effect. The testis was then grasped by an assistant who positioned the epididymis posteriorly, so that anterior testis was directly beneath the stretched scrotal skin. The subcutaneous tissue along the lateral or medial aspect of the testis was then injected with 0.5 to 1cc Lignocaine.

Care was taken to avoid injecting the anesthetic solution into tunica albuginea, so that underlying testicular architecture is not disturbed. Testicular sensation was elicited prior to and after the block was performed. Aspiration was done on single sided testis, bilateral testicular aspiration was done when the size of the testis varied on both the sides. The procedure of non-aspiration needle sampling was done in cases of infertility using a 23 gauge needle. Smears were immediately assessed for adequacy under the microscope and FNAC was repeated if necessary. The aspirate was immediately transferred to the albuminised slides and smear was made. The smears were air dried. In the same sitting with minimal scrotal incision open testicular biopsy was performed and fixed in Bouin's fluid. The incision was sutured with catgut and dressing made. They were no complications except for minimal pain and tenderness, which lasted for few hours. In cases surgical correction for varicocele was necessary the procedure was done in theater after spinal anesthesia.

FNAC smears were stained with Leishman's stain and was evaluated basing on the scoring system put forth by Foresta et al. ${ }^{5}$ for male infertility. At least 500 cells were counted. The following indices were evaluated (Table 1).

Table 1: Cytological scoring system based on Foresta et al.

\begin{tabular}{|c|c|c|}
\hline $\begin{array}{l}\text { Cytological } \\
\text { findings }\end{array}$ & Indices & Interpretation \\
\hline \multirow{2}{*}{$\begin{array}{l}\text { Most of native } \\
\text { cell seen }\end{array}$} & $\begin{array}{l}\text { Sertoli index } \\
50 \% \text { or below }\end{array}$ & \multirow{2}{*}{ Normal } \\
\hline & $\begin{array}{l}\text { Spermatic index } \\
50 \% \text { or below }\end{array}$ & \\
\hline \multirow{2}{*}{$\begin{array}{l}\text { Most of native } \\
\text { cells seen }\end{array}$} & $\begin{array}{l}\text { Sertoli index } \\
\text { above } 50 \%\end{array}$ & \multirow{2}{*}{ Hypospermatogenesis } \\
\hline & $\begin{array}{l}\text { Spermatic index } \\
50 \% \text { or below }\end{array}$ & \\
\hline $\begin{array}{l}\text { Germ cells } \\
\text { identified only } \\
\text { to a particular } \\
\text { level of } \\
\text { maturation }\end{array}$ & $\begin{array}{l}\text { Sertoli index } \\
50 \% \text { or below } \\
\text { Spermatic index } \\
\text { zero }\end{array}$ & Maturation arrest \\
\hline $\begin{array}{l}\text { Germ cells } \\
\text { identified only } \\
\text { to a particular } \\
\text { level of } \\
\text { maturation }\end{array}$ & $\begin{array}{l}\text { Sertoli index } \\
\text { above } 50 \% \\
\text { Spermatic index } \\
\text { zero }\end{array}$ & $\begin{array}{l}\text { Maturation arrest }+ \\
\text { Hypospermatogeneis }\end{array}$ \\
\hline $\begin{array}{l}\text { Spermatozoa } \\
\text { out number } \\
\text { other native } \\
\text { cells }\end{array}$ & $\begin{array}{l}\text { Sertoli index } \\
50 \% \text { or below } \\
\text { Spermatic index } \\
\text { above } 50 \%\end{array}$ & Duct obstruction \\
\hline $\begin{array}{l}\text { Sertoli cells } \\
\text { only seen }\end{array}$ & $\begin{array}{l}\text { Sertoli index } \\
100 \% \\
\text { Spermatic index } \\
\text { zero }\end{array}$ & $\begin{array}{l}\text { Total atrophy/Sertoli } \\
\text { cell } \\
\text { only syndrome }\end{array}$ \\
\hline
\end{tabular}

- $\quad$ Spermatic index (Number of spermatozoa per 100 spermatogenic cells

- Sertoli index (Number of sertoli cells per 100 cells counted)

The smears and biopsies were grouped under six headings

1. Normal spermatogenesis

2. Hypospermatogenesis

3. Maturation arrest

4. Maturation arrest with hypospermatogenesis

5. Duct obstruction

6. Total atrophy/Sertoli cell only syndrome 


\section{RESULTS}

In the present study fine needle aspiration was done on 39 patients who had azoospermia on semen analysis. The commonest group with infertility were in the age group 21-30years $(n=25,64.10 \%)$ (Table 2).

Table 2: Age wise distribution of cases with azoospermia: 39 cases.

\begin{tabular}{|c|c|c|}
\hline Age & $\begin{array}{l}\text { No. of cases } \\
(n=39)\end{array}$ & Percentage \\
\hline $10-20$ years & 01 & 2.56 \\
\hline $21-30$ years & 25 & 64.10 \\
\hline $31-40$ years & 13 & 33.33 \\
\hline
\end{tabular}

The testicular size was normal in $87.17 \% \quad(n=34)$ of subjects and $12.82 \%(n=5)$ had small testis. Out of 39 subjects with azoospermia $38.46 \%$ subjects had varicocele. Out of 12 cases with duct obstruction varicocele was seen in 10 cases $(83.33 \%)$. Out of 39 cases of azoospermia 9 cases had bilateral varicocele $(23.07 \%)$ and 6 cases $(15.38 \%)$ had unilateral varicocele predominantly on left side. The causes for azoospermia were; hypospermatogenesis with maturation arrest $(4 / 39,10.25 \%)$, duct obstruction $(12 / 39,30.76 \%)$ (Figure $1,1 \mathrm{~A})$ maturation arrest $(7 / 39,17.94 \%)$, testicular atrophy $(10 / 39,25.64 \%)$ (Figure 2, 2A) and sertoli cell only syndrome $(2 / 39.5 .12 \%)$. In two cases the cytology was inadequate and showed features of testicular atrophy on biopsy. The tunica albuginea was very much thickened hence difficult to aspirate (Table 3).

Table 3: Clinical, cytological and radiological evaluation (Doppler) of cases with azoospermia.

\begin{tabular}{|c|c|c|c|c|c|c|c|}
\hline $\begin{array}{l}\text { Morphological types on } \\
\text { cytology }\end{array}$ & $\begin{array}{l}\text { No. of } \\
\text { cases } \\
(n=39)\end{array}$ & Physical evaluation & $\begin{array}{l}\text { Testicular } \\
\text { size }\end{array}$ & $\begin{array}{l}\text { Bilateral } \\
\text { varicocele } \\
\text { (Doppler) }\end{array}$ & $\begin{array}{l}\text { Unilateral } \\
\text { varicocele } \\
\text { (Left side) }\end{array}$ & $\begin{array}{l}\text { Unilateral } \\
\text { varicocele } \\
\text { (Right side) }\end{array}$ & $\begin{array}{l}\text { No } \\
\text { Varicocele }\end{array}$ \\
\hline $\begin{array}{l}\text { Hypospermato genesis with } \\
\text { maturation arrest }\end{array}$ & 4 & Normal & Normal & 1 & 1 & - & 2 \\
\hline Maturation arrest & 7 & Normal & Normal & 1 & 1 & - & 5 \\
\hline Duct obstruction & 12 & Normal & Normal & 6 & 3 & 1 & 2 \\
\hline Sertoli cell only syndrome & 2 & Normal & Normal & - & - & - & 2 \\
\hline Testicular atrophy & 10 & Normal & $\begin{array}{l}\text { 6-normal } \\
\text { 4-small }\end{array}$ & & - & - & 10 \\
\hline Inadequate aspiration & 2 & Normal & Normal & 1 & - & - & 1 \\
\hline Total & 39 & & & & & & \\
\hline
\end{tabular}

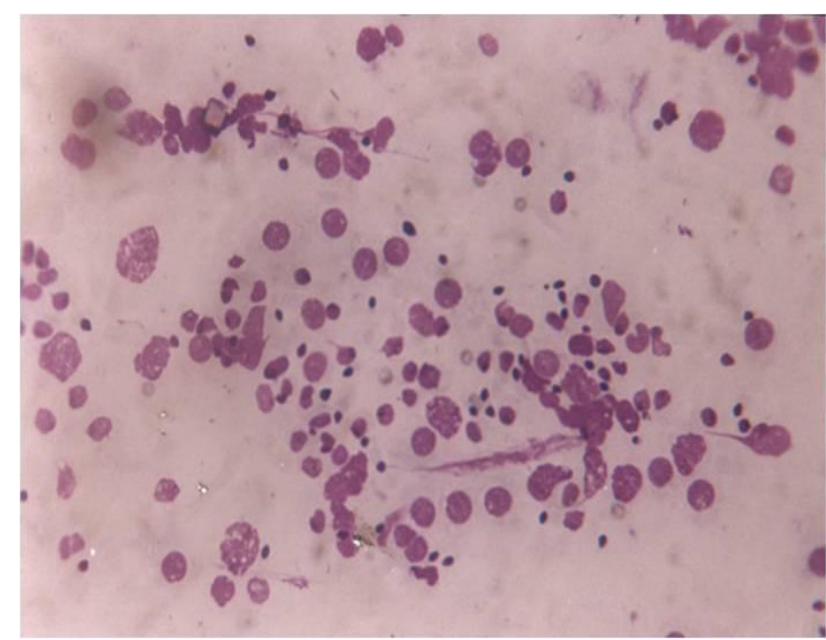

Figure 1: FNA smear of duct obstruction showing spermatozoa out number other native cells (Leishman stain, 400x).

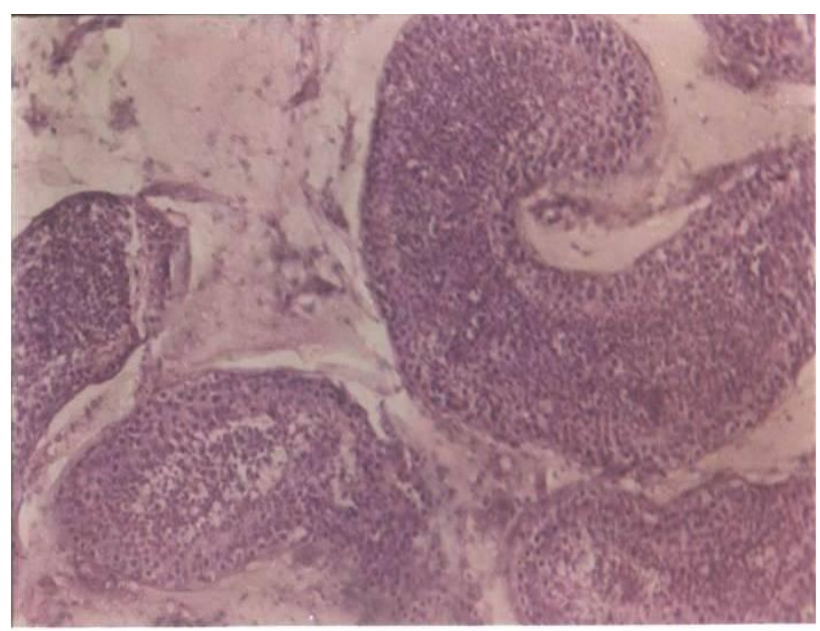

Figure 1A: Histopathology of Duct obstruction with filling of the lumen by spermatogenic cells and movement of spermatozoa towards basement membrane. (H\&E, 400x). 


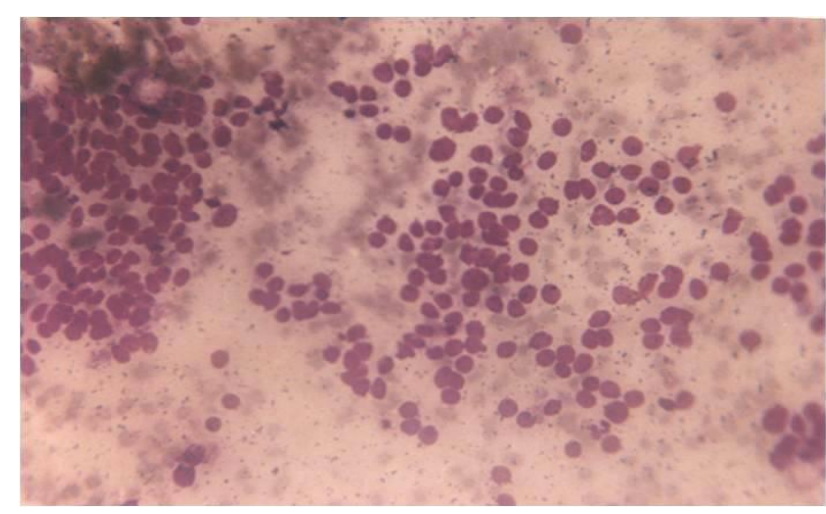

Figure 2: FNA smear of Testicular atrophy showing sertoli cells and undifferentiated spermatogonia (Leishman stain, 200x).

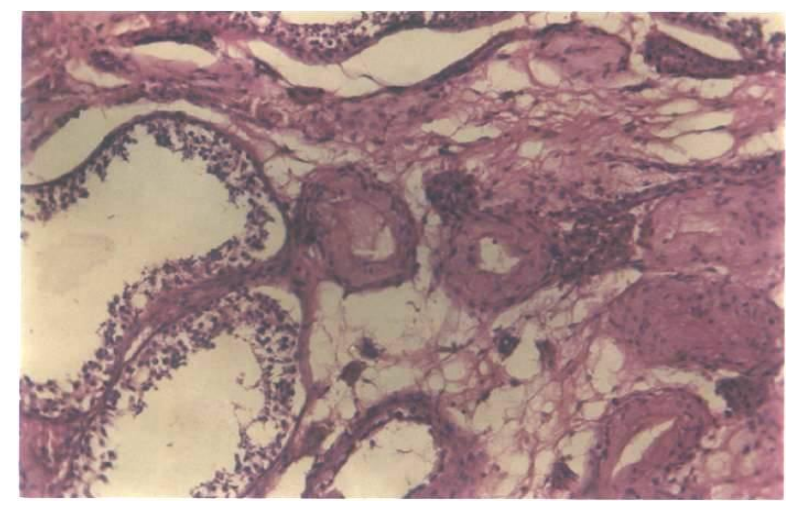

Figure 2A: Histopathology of Testicular atrophy showing atrophic tubules and hyalinised tubules

(H\&E, 400x).

In two cases there was female distribution of fat and gynecomastia. One was associated with normal size testis and other with small size of testis. They were clinically suspected to be Klinefelters syndrome and confirmed on histopathology and karyotyping (Figure 3, 3A). Out of five cases with small sized testis four cases had testicular atrophy secondary to mumps infection on histopathology and six cases with normal sized testis had testicular atrophy on histopathology.

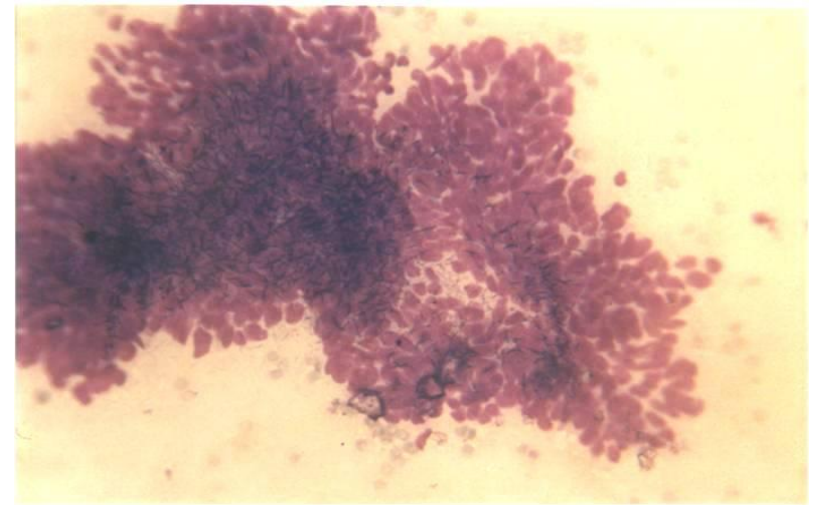

Figure 3: FNA smear of Klinefeltors syndrome showing Leydig cell hyperplasia (Leishman stain, 200x).

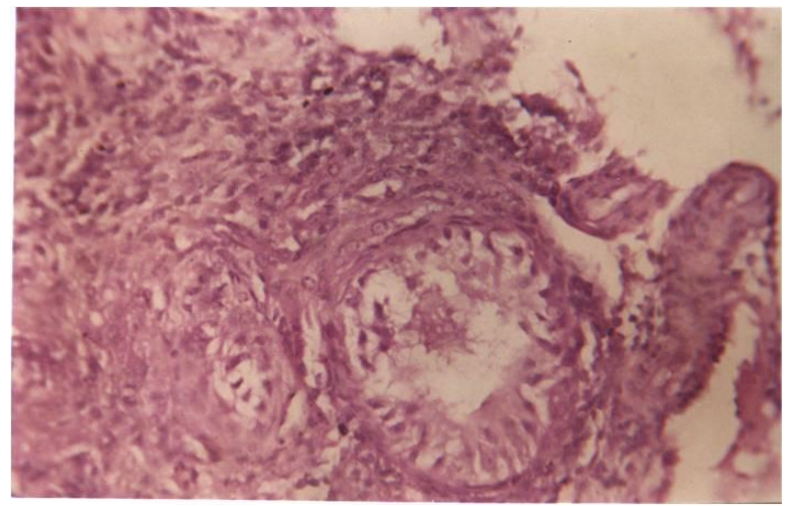

Figure 3A: Histopathology of Klinefeltors syndrome showing Leydig cell hyperplasia and atrophic tubules (H\&E, 400x).

Out of 37 cases with azoospermia 33 cases (89.18\%) showed correlation between cytology and histopathology. In 4 cases no correlation was seen between cytology and histopathology. These 4 cases were diagnosed as duct obstruction on cytology and showed normal spermatogenesis on histopathology. This error could be due to the broader range given in the scoring system for duct obstruction on FNAC (Table 4).

Table 4: Cyto-histopathological correlation: 37 cases available.

\begin{tabular}{|lllll|}
\hline Cases & $\begin{array}{l}\text { Diagnosis on } \\
\text { cytology }\end{array}$ & $\begin{array}{l}\text { Correlated } \\
\text { cases }\end{array}$ & $\begin{array}{l}\text { Non- } \\
\text { correlated } \\
\text { cases }\end{array}$ & Percentage correlation \\
\hline $\begin{array}{l}\text { Hypospermato genesis } \\
\text { with maturation arrest }\end{array}$ & 4 & 4 & - & 100 \\
\hline Maturation arrest & 7 & 7 & - & 100 \\
\hline Duct obstruction & 12 & 8 & 4 & 66.66 \\
\hline Sertoli cell only syndrome & 2 & 2 & - & 100 \\
\hline Klinefelters syndrome & 2 & 2 & - & 100 \\
\hline Testicular atrophy & 10 & 10 & - & 100 \\
\hline Total & 37 & 33 & 4 & $\begin{array}{l}\text { Overall correlation } \% \\
89.18 \%\end{array}$ \\
\hline
\end{tabular}




\section{DISCUSSION}

The assessment of male infertility involves a clinical examination for gonadal development and secondary sexual characteristics, Semen analysis, hormonal investigations and morphological examination of testicular biopsy. Open biopsy has proven to be an important procedure to clarify the pathogenesis of male infertility and to determine the prognosis. However this method is invasive and traumatic and the risk increases when done on both sides. Therefore needle puncture has been proposed as an alternative method.

Posner and Huhner first used testicular puncture biopsies in the investigation of human infertility that examined unstained samples for spermatozoa. ${ }^{6}$ Later fine needle aspiration of the testis pioneered by Obrant and Persson (1965) was proposed as a non-invasive technique. ${ }^{7}$

Characterizing the cell types in cytological smears was straightforward, with not much difficulty in recognizing germ cells and sertoli cells. The material aspirated by FNAC is adequate and the various cell types can be identified by their distinctive morphology. Some authors have attempted to quantitatively analyze the population of germ cells, sertoli cells and spermatozoa in the cytological smear so as to reach a diagnosis. ${ }^{5}$

Azoospermia is present in about $10-15 \%$ of men evaluated for infertility and represents the final result of different testicular alterations, ranging from normal spermatogenesis with seminal tract obstruction or absence of vas deferens (obstructive azoospermia) to different problems of the spermatogenic process including hypospermatogenesis, maturation arrest and complete absence of germ cells or sertoli cell only syndrome (non-obstructive azoospermia). ${ }^{8,9}$

Basin Sh. Ahmed ${ }^{10}$ analyzed 95 cases of azoospermia. Spermatocytic arrest and sertoli cell only syndrome patterns in testicular FNAC of azoospermic patients were the major two pathological findings (54.8\%).Age ranged from 16-35 years with period of infertility more than one year. Adequate samples were obtained in $88.4 \%$ of cases. Anand Kumar Verma et al. ${ }^{11}$ analyzed 275 azoospermic males. The causes of azoospermia were hypospermatogenesis (82.18\%), testicular atrophy (47.27\%), maturation arrest (13.09\%), sertoli cell only syndrome $(5.09 \%)$ and Leydig cell hyperplasia (1.09\%). Adhikari $\mathrm{RC}^{12}$ subjected 101 azoospermic males to fine needle aspiration cytology. In 99 cases the aspiration was adequate for classifying into different categories: sertoli cell only syndrome (45.54\%), hypospermatogenesis $(9.90 \%)$, tubular atrophy $(9.90 \%)$ and maturation arrest $(5.94 \%)$. Cyto-histopathological correlation was seen in $100 \%$ of cases.

Kumar R et al. ${ }^{13}$ analyzed 10 cases of azoospermia due to obstruction of the vasoepididymal junction $60 \%$ had hypospermatogenesis and in $40 \%$ of cases the FNA showed maturation arrest. In the study by Abraham
Kurien et al. ${ }^{14}$ a total of 57 patients were analysed. Out of 37 patients with azoospermia 12 patients were detected to have varicoceles $(32.43 \%)$ ).In the study by S. P. Yadav et al. ${ }^{15}$ analyzed 25 patients with infertility $4 \%$ presented with left sided varicocele in 21 patients with azoospermia. Sixty nine percent of cases had normal sized testis and $62.5 \%$ had small sized testis with diagnosis of sertoli cell only syndrome or testicular atrophy.

In the present study duct obstruction, maturation arrest at spermatocytic and spermatid level and testicular atrophy constituted the major pathological group (74.35\%). Leydig cell hyperplasia was seen on cytology in two cases of Klinefeltor syndrome $(5.12 \%)$. Age ranged between 21-30 years $(64.10 \%)$ with period of infertility more than one year. Adequate samples were obtained in $94.87 \%$ of cases. In diagnosing a correctable posttesticular cause for infertility in those patients with azoospermia genesis the accuracy of fine needle aspiration cytology compared to histopathology in the present study was $66.66 \%$.Overall cyto-histopathological correlation percentage in the present study was $89.18 \%$. Madhu S. Agarwal et al. ${ }^{16}$ and Han U et al. ${ }^{17}$ showed accuracy of $100 \%$ and $91.6 \%$ respectively in their studies.

\section{CONCLUSIONS}

1. The technique of testicular FNAC is simple, inexpensive and minimally traumatic. More than 1 specimen can be taken safely.

2. Testicular FNAC gives an accuracy of $89.18 \%$ in determining the causes of azoospermia.

3. The material aspirated by FNAC is adequate and the various cell types can be identified by their distinctive morphology. This study proves that FNAC can evaluate accurately all classically defined histologic types.

4. FNAC obtained insufficient smears mainly in atrophied testes.

5. The accuracy of diagnosing normal spermatogenic activity in obstructive azoospermia by FNAC was $100 \%$.

6. For evaluating the spermatogenic activity in male infertility it appears that a unilateral FNAC or biopsy is sufficient for diagnosis. Bilateral FNACs and biopsies can be restricted to patients in whom there is appreciable difference in testicular size or consistency.

Funding: No funding sources

Conflict of interest: None declared

Ethical approval: The study was approved by the institutional ethics committee 


\section{REFERENCES}

1. Max Huhner. Sterility in the male and female and its treatment. New York, 1913. The value of the spermatozoa test in sterility. Urol Cutan Rev; St. Louis. 1914;18:587-97.

2. Bayasgalan G, Naranbat D, Tsedmaa B, Tsogmaa B, Sukhee D, Amarjargal O, et al. Clinical patterns and major causes of infertility in Mongolia. J Obstet Gynaecol Res. 2004;30:386-93.

3. Jarow JP, Espeland MA, Lipshultz LI. Evaluation of the azoospermic patient. J Urol. 1989;142:62-5.

4. Mehrotra R, Chaurasia D. Fine needle aspiration cytology of the testis as the first line diagnostic modality in azoospermia: a comparative study of cytology and histology. Cytopathology. 2008;19:363-8.

5. Foresta C, Varotto A, Scandellari C. Assessment of testicular cytology by fine needle aspiration as a diagnostic parameter in the evaluation of the azoospermic subject. Ferti Steril. 1992;57:858.

6. Huhner M. Aspirations of the testicle in the diagnosis and prognosis of sterility. J Urol. 1928;19(1):31.

7. Persson PS, Ahren C, Obrant KO. Aspiration biopsy smear of testis in azoospermia: cytology versus histological examination. Scand J Urol Nephrol. 1971;5:22.

8. Yildiz Aktas IZ, Monacose, Khalbuss WE, Parwani AV, Jaffe TM, Pantanowitz L. Testicular touch preparation cytology in the evaluation of male infertility. Cytol J. 2011;8:24.

9. Bettella A, Ferlin A, Menegazzo M, Ferigo M, Tavolini IM, Bassi PE, et al. Testicular fine needle aspiration as a diagnostic tool in non-obstructive azoospermia. Asian J Androl. 2005;7:289-94.
10. Basin Sh. Ahmed. Cytological findings of testicular fine needle aspiration in a sample of azoospermic Iraqi patients. Mustan Siriya Med J. 2012;11:2.

11. Anand Kumar Verma, Debdatta Basu, Gita Jayaram. Testicular cytology in azoospermia. Diagn Cytopathol. 1993;9:37-42.

12. Adhikari RC. Testicular fine needle aspiration cytology in azoospermic males. Nepal Med Coll J. 2009;11(2):88-91.

13. Kumar R, Gautam G, Gupta NP, Arun M, Dada R, Kuchenak Gupta SK, et al. Role of testicular fine needle aspiration cytology in infertile men with clinically obstructive azoospermia. Natl Med J India. 2006;19(1):18-20.

14. Abraham Kurien, Kim Mammen, Sunitha Jacob. Role of fine needle aspiration cytology (FNAC) of testes in male infertility. Indian $\mathbf{J}$ Urol. 2003;19(2):140-4.

15. Yadav SP, Gopal M, Chadha I, Gulati P, Sharma R, Marya SK, et al. Comparative evaluation of the needle aspiration cytology and biopsy of testis in diagnosis of male infertility. J Indian Med Assoc. 1997;95(5):129-34.

16. Madhu S, Agarwal Atul Gupta, Kiran Chaturvedi, Prashant L. Assessment of the utility of testicular FNAC in infertile males with special reference to differential counts. Indian J Urol. 2004;20(2):148-53.

17. Han U, Adabag A, Koybasioglu F, Onal BU. Clinical value of cell count and indices in testicular fine needle aspiration cytology in primary infertility diagnostic performances compared with histology. Anal Quant Cytol Histol. 2006;28(6):331-6.

DOI: $10.18203 / 2320-1770 . i j r \operatorname{cog} 20150067$

Cite this article as: Prasad U, Prasad U. Testicular cytology in azoospermia. Int J Reprod Contracept Obstet Gynecol 2015;4:647-52. 